University of Nebraska - Lincoln

DigitalCommons@University of Nebraska - Lincoln

Disentangling root responses to climate change in a semiarid grassland

\author{
Yolima Carrillo \\ University of Wyoming \\ Feike A. Dijkstra \\ University of Sydney, feike.dijkstra@sydney.edu.au \\ Dan LeCain \\ USDA-ARS, dan.lecain@ars.usda.gov \\ Jack A. Morgan \\ USDA-ARS \\ Dana Blumenthal \\ USDA-ARS, Dana.Blumenthal@ars.usda.gov \\ See next page for additional authors
}

Follow this and additional works at: https://digitalcommons.unl.edu/usdaarsfacpub

Carrillo, Yolima; Dijkstra, Feike A.; LeCain, Dan; Morgan, Jack A.; Blumenthal, Dana; Waldron, Sarah; and Pendall, Elise, "Disentangling root responses to climate change in a semiarid grassland" (2014). Publications from USDA-ARS / UNL Faculty. 1604.

https://digitalcommons.unl.edu/usdaarsfacpub/1604

This Article is brought to you for free and open access by the U.S. Department of Agriculture: Agricultural Research Service, Lincoln, Nebraska at DigitalCommons@University of Nebraska - Lincoln. It has been accepted for inclusion in Publications from USDA-ARS / UNL Faculty by an authorized administrator of DigitalCommons@University of Nebraska - Lincoln. 


\section{Authors}

Yolima Carrillo, Feike A. Dijkstra, Dan LeCain, Jack A. Morgan, Dana Blumenthal, Sarah Waldron, and Elise Pendall 


\title{
Disentangling root responses to climate change in a semiarid grassland
}

\author{
Yolima Carrillo · Feike A. Dijkstra · Dan LeCain · \\ Jack A. Morgan · Dana Blumenthal · Sarah Waldron · \\ Elise Pendall
}

Received: 19 August 2013 / Accepted: 20 February 2014 / Published online: 19 March 2014 (C) Springer-Verlag Berlin Heidelberg 2014

\begin{abstract}
Future ecosystem properties of grasslands will be driven largely by belowground biomass responses to climate change, which are challenging to understand due to experimental and technical constraints. We used a multi-faceted approach to explore single and combined impacts of elevated $\mathrm{CO}_{2}$ and warming on root carbon (C) and nitrogen $(\mathrm{N})$ dynamics in a temperate, semiarid, native grassland at the Prairie Heating and $\mathrm{CO}_{2}$ Enrichment experiment. To investigate the indirect, moisture
\end{abstract}

Communicated by Susanne Schwinning.

Electronic supplementary material The online version of this article (doi:10.1007/s00442-014-2912-z) contains supplementary material, which is available to authorised users.

Y. Carrillo $\cdot$ E. Pendall

Department of Botany and Program in Ecology, University of Wyoming, Laramie, WY 82071, USA

Y. Carrillo · F. A. Dijkstra

Department of Environmental Sciences, Faculty of Agriculture and Environment, University of Sydney, Level 4, Biomedical Building-C81, Australian Technology Park, Eveleigh, NSW

2015, Australia

Y. Carrillo $(\varangle) \cdot$ E. Pendall

Hawkesbury Institute for the Environment, University of Western Sydney, UWS Hawkesbury Campus, Locked Bag 1797, Penrith, NSW 2751, Australia

e-mail: y.carrillo@uws.edu.au

D. LeCain · J. A. Morgan · D. Blumenthal

USDA-ARS Rangeland Resources Research Unit, Crops

Research Laboratory, 1701 Center Ave, Fort Collins, CO 80526,

USA

S. Waldron

USDA-ARS, Northern Great Plains Research Laboratory, 1701

10th Avenue SW, Mandan, ND 58554, USA mediated effects of elevated $\mathrm{CO}_{2}$, we included an irrigation treatment. We assessed root standing mass, morphology, residence time and seasonal appearance/disappearance of community-aggregated roots, as well as mass and $\mathrm{N}$ losses during decomposition of two dominant grass species $\left(\mathrm{a} \mathrm{C}_{3}\right.$ and $\mathrm{a} \mathrm{C}_{4}$ ). In contrast to what is common in mesic grasslands, greater root standing mass under elevated $\mathrm{CO}_{2}$ resulted from increased production, unmatched by disappearance. Elevated $\mathrm{CO}_{2}$ plus warming produced roots that were longer, thinner and had greater surface area, which, together with greater standing biomass, could potentially alter root function and dynamics. Decomposition increased under environmental conditions generated by elevated $\mathrm{CO}_{2}$, but not those generated by warming, likely due to soil desiccation with warming. Elevated $\mathrm{CO}_{2}$, particularly under warming, slowed $\mathrm{N}$ release from $\mathrm{C}_{4}$-but not $\mathrm{C}_{3}$-roots, and consequently could indirectly affect $\mathrm{N}$ availability through treatment effects on species composition. Elevated $\mathrm{CO}_{2}$ and warming effects on root morphology and decomposition could offset increased $\mathrm{C}$ inputs from greater root biomass, thereby limiting future net $\mathrm{C}$ accrual in this semiarid grassland.

Keywords Elevated $\mathrm{CO}_{2} \cdot$ Warming $\cdot$ Roots · Decomposition · Production · Death · Turnover . Morphology

\section{Introduction}

Temperate grasslands are considered carbon (C) sinks (Jones and Donnelly 2004, Robinson 2007), due, to a large extent, to the substantial supply of $\mathrm{C}$ to soil from belowground biomass (Jackson et al. 1996). The majority of $\mathrm{C}$ assimilation in grasslands is allocated belowground (Hui 
and Jackson 2006), particularly as roots-which in grasslands are mainly fine roots smaller than $2 \mathrm{~mm}$ in diameter (Jackson et al. 1997). In fact, temperate grasslands have the greatest density of fine root biomass among biomes; while they occupy $7 \%$ of the land area, they hold $17 \%$ of global fine root biomass and $41 \%$ of the fine root length, greater portions than any other biome (Jackson et al. 1997). Further, fine roots contain a large proportion of the ecosystem's nitrogen $(\mathrm{N})$, and their recycling via litter decomposition should impact ecosystem level $\mathrm{N}$ and productivity (Parton et al. 2007a), feeding back to $\mathrm{C}$ storage. Thus, understanding the response of fine roots to climate change and their role in soil $\mathrm{C}$ and $\mathrm{N}$ dynamics is paramount to predicting the global C balance (Norby and Jackson 2000). However, while their small diameter, belowground location, chemical composition and turnover rates distinguish them from aboveground plant pools, studying fine roots and their dynamics is methodologically challenging, and thus root dynamics remain poorly understood.

Climate change is anticipated to involve concomitant increases in $\mathrm{CO}_{2}$ concentrations and temperature (Solomon et al. 2007), but studies have mostly looked at impacts of individual factors. Elevated $\mathrm{CO}_{2}$ has positive to neutral effects on grassland root standing stocks (Arnone et al. 2000), but responses can be dependent on individual species (Anderson et al. 2010; LeCain et al. 2006). Both root production and mortality have been observed to increase under elevated $\mathrm{CO}_{2}$ in semiarid (Milchunas et al. 2005) and mesic grasslands (Allard et al. 2005). Warming studies on root dynamics in grasslands are scarce and findings include increases, decreases and no effects of warming on root biomass, production and mortality (Bai et al. 2010; De Boeck et al. 2008; Fitter et al. 1999). The few available observations of elevated $\mathrm{CO}_{2}$ in combination with warming from individual species (Volder et al. 2007; Wan et al. 2004) and a Mediterranean grassland (Shaw et al. 2002) have suggested complex, non-additive effects on root production and mortality, which may depend on root diameter (Pilon et al. 2013). Production and mortality are commonly assessed with minirhizotron observations of appearance and disappearance of roots. However, disappearance encompasses both death and decomposition of material (Norby and Jackson 2000), a fact often ignored, and which may mask potential decoupling of these two processes.

In water-limited systems such as the semiarid mixed grass prairies of central North America, where our study took place, changes in water availability generated by climate change are expected to be important for root dynamics. Elevated $\mathrm{CO}_{2}$ and warming have considerable and opposite impacts on soil water (increase with elevated $\mathrm{CO}_{2}$ and decrease with warming; Morgan et al. 2011). These effects are likely to affect not only root decomposition, but also production, mortality (Milchunas et al. 2005) and morphology (Ostonen et al. 2007). In addition, both factors can alter plant community composition (Morgan et al. 2011), which, given species traits differences, can also affect the root-soil $\mathrm{C}$ and $\mathrm{N}$ flux. Moreover, soil moisturedriven changes in the $\mathrm{N}$ cycle and soil $\mathrm{N}$ pools observed for this system with climate change (Carrillo et al. 2012; Dijkstra et al. 2010), are likely to influence the processes responsible for root dynamics.

Root morphology is an overlooked variable that may mediate changes in root dynamics with climate change. Root morphological parameters are responsive to atmospheric $\mathrm{CO}_{2}$ (Anderson et al. 2010) and warming (Bjork et al. 2007), and have been linked with root turnover and lifespan (Eissenstat et al. 2000; Klumpp and Soussana 2009). Climate factors may alter community level root morphology by modifying plant community composition and/or through species-specific responses (Anderson et al. 2010). We are not aware of field assessments of root morphology under combined elevated $\mathrm{CO}_{2}$ and warming in intact grasslands.

Root-derived matter is a major source of stable soil C and N (Crow et al. 2009; Garcia-Pausas et al. 2012). Studies of decomposition under climate change have mostly focused on aboveground litter. However, belowground decomposition rates and their regulation differ from those aboveground (Adair et al. 2008; Hobbie et al. 2010; Parton et al. 2007a), and thus climate change may affect them differently. Elevated $\mathrm{CO}_{2}$ and warming effects on litter decomposition occur through changes in litter degradability and the soil environment, including soil moisture, nutrient availability and microbial community structure (Norby et al. 2001). Most research has evaluated impacts of climate factors via either changes in litter chemistry alone or in combination with changes in the soil environment (Chapman et al. 2005; Gorissen and Cotrufo 2000; King et al. 2005), but the independent, micro environment-mediated impacts on root decomposition occurring in the mineral soil have rarely been studied. However, changes in the soil environment can have stronger effects on decomposition than changes in litter chemistry (Aerts 2006; Cheng et al. 2010). Our previous work demonstrated that elevated $\mathrm{CO}_{2}$ and warming substantially altered the aboveground and soil environment in the native mixed-grass prairie (Carrillo et al. 2012; Dijkstra et al. 2012; Morgan et al. 2011; Nie et al. 2013), which may have affected root decomposition.

The complex nature of root responses to climate factors and the potential for interactive effects together with the absence of medium to long-term field experimental data currently limit predictions of biomass dynamics and its incorporation into ecosystem and global models. Further, very few studies have evaluated the dynamics of root $\mathrm{N}$ during decomposition in climate change field experiments, which is necessary to inform the modelling of 
potential nutrient regulated processes. We combine field community-level observations of fine root standing mass, residence time, morphology and seasonal production and disappearance with direct decomposition measurements of two dominant grass species to assess the impact of elevated $\mathrm{CO}_{2}$, warming and their combination on root $\mathrm{C}$ and $\mathrm{N}$ dynamics in an intact, semiarid, temperate native grassland in Wyoming, USA. In order to investigate the role of indirect, moisture mediated effects of elevated $\mathrm{CO}_{2}$, we also assessed these variables under an irrigation treatment. Our observations spanned a period covering 4 years of warming and five seasons of elevated $\mathrm{CO}_{2}$. We hypothesised that under future high $\mathrm{CO}_{2}$ and warming conditions root production would increase due to enhanced plant water relations and $\mathrm{C}$ supply with $\mathrm{CO}_{2}$ and stimulated soil exploration with warming-induced drying. We expected that root disappearance and decomposition would not respond to future conditions due to counteractive effects of $\mathrm{CO}_{2}$ and warming on soil moisture. With increased production and neutral impacts on disappearance, we hypothesised greater root standing mass. Finally, we anticipated increased biomass would be accompanied by changes in root morphology due to a combination of changes in species composition and resource use strategies.

\section{Methods}

Study site

The ecosystem is a northern mixed grass prairie dominated by the perennial $\mathrm{C}_{4}$ grass Bouteloua gracilis (H.B.K) Lag. and two $\mathrm{C}_{3}$ grasses, Hesperostipa comata Trin and Rupr. and Pascopyrum smithii (Rydb.), with ca. $20 \%$ of the biomass composed of sedges and forbs. Belowground biomass is ca. three times that of shoots, with ca. $75 \%$ of it located in the first $0-15 \mathrm{~cm}$ depth (Supporting information, Fig. S1). The PHACE (Prairie Heating and $\mathrm{CO}_{2}$ Enrichment) experimental site is located at the USDA-ARS High Plains Grassland Research Station (1,930 m a.s.1.), $15 \mathrm{~km}$ west of Cheyenne, WY, USA $\left(41^{\circ} 11^{\prime} \mathrm{N}, 104^{\circ} 54^{\prime} \mathrm{W}\right)$. Annual precipitation is $384 \mathrm{~mm}$, with ca. $60 \%$ falling during the growing season (March-September); mean air temperatures are $17.5^{\circ} \mathrm{C}$ in summer and $-2.5{ }^{\circ} \mathrm{C}$ in winter (NOAA 1994). Soils are Mollisols (fine-loamy, mesic Aridic Argiustoll, mixed Ascalon and Altvan series), with a $\mathrm{pH}$ of 7.0 and organic soil $\mathrm{C}$ concentration of $1.9 \%(\mathrm{SD}=0.27)$ at 0-5 cm (Carrillo et al. 2011).

\section{Experimental set up}

The PHACE experiment exposes plots to a factorial combination of $\mathrm{CO}_{2}$ and temperature (ambient $\mathrm{CO}_{2}$ and ambient temperature: ct; ambient $\mathrm{CO}_{2}$ and elevated temperature: cT; elevated $\mathrm{CO}_{2}$ and ambient temperature: $\mathrm{Ct}$; elevated $\mathrm{CO}_{2}$ and elevated temperature: $\mathrm{CT}$ ) with five replications. Elevated $\mathrm{CO}_{2}$ during the growing season $(600 \pm 40 \mathrm{ppmv})$ is accomplished via Free Air $\mathrm{CO}_{2}$ Enrichment technology (Miglietta et al. 2001) installed in 3.4-m diameter rings. Increased canopy temperature $\left(1.5{ }^{\circ} \mathrm{C}\right.$ daytime $/ 3{ }^{\circ} \mathrm{C}$ night year round) is generated with an hexagonal array of 1,000-watt Mor FTE infrared heaters (Comstock Park, MI, USA) attached to a frame $1.5 \mathrm{~m}$ above the ground (Kimball et al. 2008). The $\mathrm{CO}_{2}$ treatment began in early April 2006 and heating in early April 2007. Five additional plots under ambient $\mathrm{CO}_{2}$ and temperature (ct-i) were irrigated during the growing season beginning in 2006 to simulate the soil water observed in the elevated $\mathrm{CO}_{2}$ plots. For this, volumetric water content (VWC) was closely monitored in each plot. In each season, $60 \mathrm{~mm}$ of water were distributed among four to five watering events in order to maintain water content in ct-i plots within ca. $3 \%$ (volumetric) that of elevated $\mathrm{CO}_{2}$ plots $(\mathrm{Ct})$.

\section{Environmental monitoring}

Soil VWC (5-15 cm depth) was monitored hourly in each plot with an Envirosmart sensor (Sentek Sensor Technologies, Stepney, Australia) situated in a central and standard location for all plots. Soil temperature was measured hourly at $3 \mathrm{~cm}$ using thermocouples. Mineral $\mathrm{N}$ availability $\left(\mathrm{NH}_{4}{ }^{+}\right.$and $\left.\mathrm{NO}_{3}{ }^{-}\right)$in soil was assessed using Plant-RootSimulator resin probes (PRSTM, Western Ag Innovations, Saskatoon, SK, Canada). In each of three separate insertion periods (13 May- 21 Oct, 2009; 21 Oct 2009-10 May 2010; 17 May-19 Oct 2010), two anion and two cation probes were inserted vertically into previously undisturbed soil. The $5.6 \mathrm{~cm}$ resin membranes covered a $2-7.6 \mathrm{~cm}$ soil depth range. At the end of each insertion period, probes were cleaned with deionised water and sent to Western $\mathrm{Ag}$ Innovations, for elution with $17.5 \mathrm{ml}$ of $0.5 \mathrm{M} \mathrm{HCl}$, and analysis with a Technicon Autoanalyzer II (Technicon Instrument Corporation, Tarrytown, NY, USA).

\section{Biomass and root morphology}

Fine root biomass and its ${ }^{12} \mathrm{C} /{ }^{13} \mathrm{C} \mathrm{C}$ isotopic composition were assessed each year in late July near the time of peak aboveground biomass from 2007 to 2010 . Three individual $3-\mathrm{cm}$ diameter, $15 \mathrm{~cm}$ deep soil cores were collected per plot and composited (75 cores, 25 plots). Fine roots $(<2 \mathrm{~mm})$ were hand-picked, washed, dried $\left(60{ }^{\circ} \mathrm{C}\right)$ and ash content was determined $\left(550{ }^{\circ} \mathrm{C}\right)$. Ash-free dry mass was converted to $\mathrm{g} \mathrm{m}^{-2}$ using bulk density measurements for each plot. Root biomass up to 2009 and assessment methods have been reported previously (Morgan et al. 2011). 
Here, we report root biomass for 2010 and $\mathrm{C}$ isotopic composition for all years, at the $0-15 \mathrm{~cm}$ depth where $75 \%$ of the below ground biomass is located (Figure S1). No treatment effects have been detected in deeper soil (Morgan et al. 2011).

Because the elevated $\mathrm{CO}_{2}$ plots were fumigated with ${ }^{13} \mathrm{C}$-depleted fuel-derived $\mathrm{CO}_{2}$, it was possible to estimate the fraction of new $\mathrm{C}$ incorporated into roots by the time of each sampling and thus its accumulation over time in these plots. For this, we used a two-part mixing model:

Fraction new $\mathrm{C}=\left(\delta^{13} \mathrm{C}_{\mathrm{er}}-\delta^{13} \mathrm{C}_{\mathrm{ar}}\right) /\left(\delta^{13} \mathrm{C}_{\mathrm{s}}-\delta^{13} \mathrm{C}_{\mathrm{ar}}\right)$

where $\delta^{13} \mathrm{C}_{\mathrm{er}}$ is the $\delta^{13} \mathrm{C}$ of the community-level roots in each elevated $\mathrm{CO}_{2}$ plot, $\delta^{13} \mathrm{C}_{\mathrm{ar}}$ is the average ${ }^{13} \mathrm{C}$ of community-level roots in the ambient $\mathrm{CO}_{2}$ plots, representing the isotopic composition prior to fumigation (evaluation of $\delta^{13} \mathrm{C}$ of community-level roots was done on the same roots collected for biomass and other variables); and $\delta^{13} \mathrm{C}_{\mathrm{s}}$ is the weighted $\delta^{13} \mathrm{C}$ of the plant shoots in each elevated $\mathrm{CO}_{2}$ plot in each year, representing the isotopic composition of newly fixed $\mathrm{C}$ at the community level (Pendall et al. 2004). To estimate this value, we harvested each species in an area of $0.75 \mathrm{~m}^{2}$ in each plot within 1 week of time of soil and root collection, analysed it separately for total biomass and $\delta^{13} \mathrm{C}$ and then calculated the weighted $\delta^{13} \mathrm{C}$ for each plot (thus accounting for treatment driven responses in community composition). Measurements of $\delta^{13} \mathrm{C}$ were done using an elemental analyzer connected to a mass spectrometer (20-20 Stable Isotope Analyzer; Europa Scientific, Cheshire, UK, for roots; Finnigan Delta ${ }^{\text {Plus }}$ XP connected to a Carlo Erba NC-2500 elemental analyzer via a Finnigan ConFlo III open-split interface, for shoots). The calculated fraction of new $\mathrm{C}$ was applied to the total pool of standing biomass to calculate new $\mathrm{C}$ biomass. From the annual rate of root $\mathrm{C}$ replacement over the 5.25 years of fumigation we calculated root $\mathrm{C}$ residence time (Pendall et al. 2004). This method assumes equal representation of species above and belowground, as well as steady-state biomass and equivalent allocation to non-structural C pools (Luo 2003).

To evaluate root morphology, approximately half of the 2010 roots $(<2 \mathrm{~mm}$ which are the great majority of the roots in this ecosystem) were hand-picked while fresh, cleaned of excess soil and arranged for digital scanning at $800 \mathrm{dpi}$ (Epson Perfection 4870). Images were analyzed automatically with WinRhizo Pro software (Regents Instruments, Inc., Quebec) for length, diameter, volume and surface area. Scanned roots were then washed, dried and weighed.

Minirhizotron observations of root production and disappearance

In early April, 2006 minirhizotron access tubes were installed at a $23^{\circ}$ angle from soil surface in each of the
25 PHACE plots we studied. Access tubes were made of clear cellulose acetate butyrate plastic with a $4.4 \mathrm{~cm}$ inside diameter, and span a horizontal distance of nearly $1 \mathrm{~m}$ and a depth of $42 \mathrm{~cm}$. Aboveground portions of the tubes were covered with reflective insulating material and a capped PVC pipe that blocked sunlight to prevent direct solar heating. Tube bottoms and tops were sealed with rubber stoppers. Tubes were placed in a central and standard location for all plots. Bitmap images (1.2 mega pixels each) were taken at $1 \mathrm{~cm}$ depth intervals from the soil surface with the Bartz BTC 100x video microscope with an indexing handle, assuring relocation in the same spot in each session (Bartz Technology Corporation, Carpinteria, CA USA). Measurements began in April 2007 (allowing 1 year for adjustment to the disturbance), and continued each year at 5-week intervals until soil freezing (usually six sessions/ year). Previous studies in a very similar grassland ecosystem suggest that 4-5 measurements per growing season (every 5-4 weeks) are adequate to assess root dynamics in semi-arid grasslands with slow root turnover times (Milchunas 2009; Milchunas et al. 2005). Since equilibration around the access tube can take years, we used the most recent data (2009 and 2010; ten sessions). Root number data were pooled over $0-15 \mathrm{~cm}$ and 15-40 soil depth. Root images were digitally analyzed using the RooTracker software (David Tremmel, Duke University, Durham, NC, USA). We report numbers of new roots produced and numbers of roots that disappeared in relation to the prior observation.

\section{Root decomposition}

Decomposition was assessed using standard buried litter bag methods with field-collected roots (e.g. Berg and McClaugherty 2003; Bontti et al. 2009; Parton et al. 2007a). While the magnitude of decay rates are likely to be somewhat impacted by the litter bag methodology, treatment effects shed light on the natural processes acting on buried tissue. Roots were collected in September 2007 from the experimental site, outside the treatment plots. Placing off-plot roots in different experimental treatments allowed us to assess the effects of $\mathrm{CO}_{2}$ and warminginduced changes in the soil environment on species-level litter decomposition. Soil $(0-15 \mathrm{~cm}$ depth) from naturally occurring mono-specific patches of the $\mathrm{C}_{4}$ grass $\mathrm{B}$. gracilis and the $\mathrm{C}_{3}$ grass $H$. comata was excavated and roots ( $<2 \mathrm{~mm}$ diameter) were hand-picked. Roots were washed free of soil and dried at $50{ }^{\circ} \mathrm{C}$. We placed $500 \mathrm{mg}$ of dried material in 3-cm $\times 6-\mathrm{cm}, 25-\mu \mathrm{m}$ pore Ankom F-57 fabric bags (Macedon, NY, USA). The pore size of the bag material should have allowed access to microbial decomposers, as well as members of the microfauna (Coleman et al. 2004). In early November 2007, five bags of each 
species were buried in each of the 25 experimental plots ( 250 bags). To bury the bags, we chiseled $3-\mathrm{cm}$ wide slots at $45^{\circ}$ angles down to $7 \mathrm{~cm}$ in depth, slipped a bag inside and gently packed the soil above. Bags were arranged in lines ca. $10 \mathrm{~cm}$ apart from each other. One bag from each species, treatment and plot was removed in early April and early October in 2008 and 2009 and finally in early October in 2010. Once removed, bags and their contents were dried at $60{ }^{\circ} \mathrm{C}$. Bags were then cut open to remove and weigh the contents. Initial pre-incubation and decomposed materials were ground to fine powder to determine mineral ash and $\mathrm{C}$ and $\mathrm{N}$ content. \% $\mathrm{C}$ and \% $\mathrm{N}$ were measured on a Finnigan Delta ${ }^{\text {Plus }}$ XP connected to a Carlo Erba NC-2500 elemental analyzer via a Finnigan ConFlo III open-split interface. Mass remaining and element percentages were both corrected for ash content (after $3 \mathrm{~h}$ at $550{ }^{\circ} \mathrm{C}$ ), so all data reported are on an ashfree basis. Mass loss rate constants $\left(k_{\mathrm{m}}\right)$ and $\mathrm{N}$ loss rate constants $\left(k_{\mathrm{n}}\right)$ were estimated by fitting a single negative exponential decay model to the values of remaining mass after constraining the intercept to be $100 \% \pm 5 \%$ (Harmon et al. 2009).

\section{Statistical analyses}

We used two-factor ANOVA to test for the effects of $\mathrm{CO}_{2}$, warming and their interactions on mean soil water and temperature, PRS-N, root biomass, and root morphology parameters. Effects of irrigation were assessed with $t$ tests comparing ct against ct-i. Minirhizotron root production and disappearance were analyzed with repeated measures ANOVA using JMP multivariate approach with plot and time as random effects, $\mathrm{CO}_{2}$ and warming as fixed effects and considering all interactions. Mass loss rate and $\mathrm{N}$ loss rate (relative to initial $\mathrm{N}$ content) constants were estimated for each plot using non-linear regression tools in SigmaPlot (version 10.0 Systat Software Inc., San Jose, CA, USA). Treatment effects on mass loss rates $(\mathrm{k})$ were assessed with three-factor $\left(\mathrm{CO}_{2}\right.$, warming, species) and two factor (irrigation, species) ANOVA with all interactions. Effects of $\mathrm{CO}_{2}$, warming and species on release of $\mathrm{N}$ with mass loss were assessed with ANCOVA $\left(\mathrm{CO}_{2}\right.$, warming, species as factors and \% mass loss as the continuous variable). Subsequently, we conducted ANCOVA for each species. Effects of irrigation were evaluated with ANCOVA (irrigation, species as factors and \% mass loss as continuous variable). Linear regressions between $\%$ mass loss and \% $\mathrm{N}$ remaining were conducted for each experimental treatment and species. ANOVA, ANCOVA and linear regressions were performed with JMP (version 7.0; SAS Institute, Cary, N.C. USA). Significant effects and relationships are reported at $p<0.05$ unless otherwise stated.

\section{Results}

Soil water, temperature and $\mathrm{N}$ availability

Percentage of soil water content was $2.4 \%$ higher under elevated $\mathrm{CO}_{2}, 0.8 \%$ lower under warming and $1.2 \%$ higher under combined elevated $\mathrm{CO}_{2}$ and warming (Table 1). The irrigation treatment increased water content by $2.2 \%$, thus closely mimicking the increase with elevated $\mathrm{CO}_{2}$ (Table 1). Warming increased soil temperature at 3 -cm depth by $2.8{ }^{\circ} \mathrm{C}$ on average across the elevated $\mathrm{CO}_{2}$ treatments (Table 1). These treatment effects on overall averages are reflective of dominant effects across seasons (see Carrillo et al. (2012) and Pendall et al. (2013)). PRSavailable $\mathrm{N}\left(\mathrm{NO}_{3}^{-}+\mathrm{NH}_{4}{ }^{+}\right)$decreased with elevated $\mathrm{CO}_{2}$ and increased with warming under ambient $\mathrm{CO}_{2}$, but was not affected by warming under elevated $\mathrm{CO}_{2}$ or by irrigation (Table 1).

\section{Root biomass and morphology}

At the time of aboveground peak biomass in 2010, after 5 years of elevated $\mathrm{CO}_{2}$ and 4 years of warming, $0-15 \mathrm{~cm}$ fine root biomass estimated from soil cores was, on average, $30 \%$ greater under elevated $\mathrm{CO}_{2}$, and was unaffected by warming (Fig. 1a). The irrigation treatment resulted in a $15 \%$ decrease in fine root biomass (Fig. 1a). Based on isotopic partitioning, we estimated that by 2010 (5.25 years

Table 1 Average soil moisture content, soil temperature and soil $\mathrm{N}$ availability (from Plant Root Simulator probes, PRS-N) under $\mathrm{CO}_{2}$, warming and irrigation treatments at PHACE

\begin{tabular}{llll}
\hline & $\begin{array}{l}\text { Soil water } \\
\text { content } \\
(\% \text { VWC })\end{array}$ & $\begin{array}{l}\text { Soil } \\
\text { temperature } \\
\left({ }^{\circ} \mathrm{C}\right)\end{array}$ & PRS-N $(\mu \mathrm{g})$ \\
\hline $\mathrm{ct}$ & $12.6(0.7)$ & $10.1(0.4)$ & $60.2(15.3)$ \\
$\mathrm{cT}$ & $11.8(0.3)$ & $13.1(0.5)$ & $116.9(24.2)$ \\
$\mathrm{Ct}$ & $15.0(0.6)$ & $9.7(0.3)$ & $37.4(10.2)$ \\
$\mathrm{CT}$ & $13.8(0.8)$ & $12.3(0.4)$ & $35.6(7.8)$ \\
$\mathrm{ct}-\mathrm{i}$ & $14.8(0.8)$ & $9.5(0.3)$ & $41.8(3.5)$ \\
$\mathrm{ANOVA}$ & & & 0.003 \\
$\mathrm{CO}_{2}$ & 0.002 & 0.2 & 0.08 \\
$\mathrm{Warming}$ & 0.09 & $<0.0001$ & 0.06 \\
$\mathrm{CO}_{2} \times$ warming & 0.8 & 0.6 & 0.15 \\
$t$ test (ct vs ct-i) & & & \\
Irrigation & 0.04 & 0.14 & \\
\hline
\end{tabular}

ct ambient $\mathrm{CO}_{2}$, unwarmed; $c T$ ambient $\mathrm{CO}_{2}$, warmed; $C t$ elevated $\mathrm{CO}_{2}$, unwarmed; $C T$ elevated $\mathrm{CO}_{2}$, warmed; $c t-i$ ambient $\mathrm{CO}_{2}$, unwarmed, irrigated plots. Moisture $(5-15 \mathrm{~cm})$ and temperature $(3 \mathrm{~cm})$ are daily averages (Nov 2007-Nov 2010). PRS-N is total $\mathrm{N}$ collected in $10 \mathrm{~cm}^{-2}$ of resin membrane at $2-7.6 \mathrm{~cm}$ in each plot between (2009 and 2010). Values are means of five replicates with standard errors in parentheses. ANOVA and $t$ test results are $p$ values 


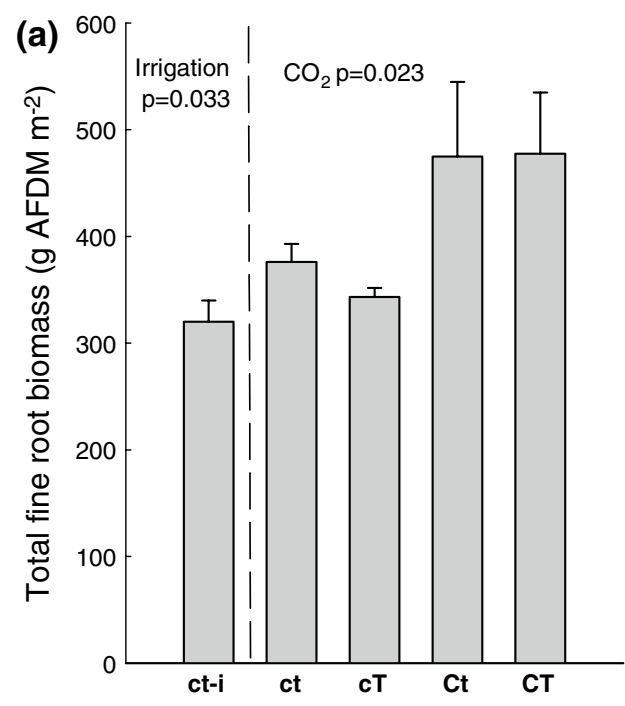

Fig. 1 Fine root biomass $(0-15 \mathrm{~cm})$ in 2010 after five seasons of elevated $\mathrm{CO}_{2}$ and four of warming (a) and new biomass in elevated $\mathrm{CO}_{2}$ treatments across years, based on isotopic partitioning (b). AFDM ash-free dry biomass; $c t$ ambient $\mathrm{CO}_{2}$, unwarmed; $c T$ ambient $\mathrm{CO}_{2}$,

since the beginning of $\mathrm{CO}_{2}$ fumigation; elevated $\mathrm{CO}_{2}$ plots only), on average, 74 and $87 \%$ of the root biomass had been replaced by "new C" in the Ct and CT treatments, respectively. The rate of replacement of root biomass over the years indicated a mean residence time of 7.0 years for $\mathrm{Ct}$ and 6.0 years for $\mathrm{C}$ (comparable to those by Milchunas et al. (2005) obtained using minirhizotron data in a similar grassland), although no significant effect of warming was detected ( $p>0.05$; Fig. 1b). Based on these estimations, the span of our observations should have allowed sufficient time for responses to experimental manipulations to develop.

Average root diameter under ambient conditions was $0.28 \mathrm{~mm}$ and decreased with elevated $\mathrm{CO}_{2}$ by $15 \%$ on average (Fig. 2a). Elevated $\mathrm{CO}_{2}$ increased specific root length (length per unit of mass) and fine root surface area per unit of root volume, particularly in combination with warming (25 and $39 \%$ increases respectively; Fig. 2b, c). Given greater total root biomass and volume (not shown), these changes translated into greater total root length and surface area. A trend towards increased tissue density in CT plots was not significant (Fig. 2d). Irrigation did not impact root morphology.

\section{Minirhizotron observations}

Overall, both root production and disappearance showed stronger seasonality at the $0-15 \mathrm{~cm}$ depth than at $15-40 \mathrm{~cm}$ depth, and in 2009 than in 2010 (Fig. 3a, b; deeper roots values in Fig. S2). Root production was highly variable over time and peaked around July in both years, coincident with peak aboveground biomass in this system (Morgan et al.

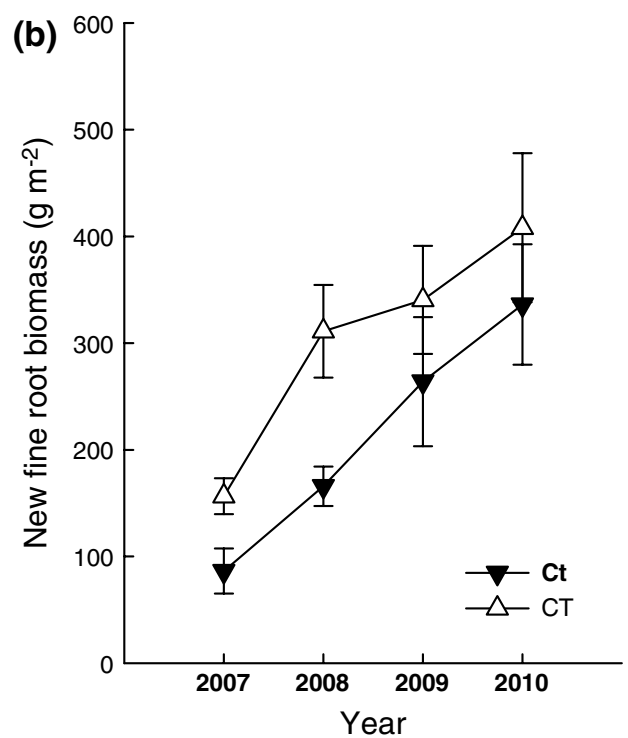

warmed; $C t$ elevated $\mathrm{CO}_{2}$, unwarmed; $C T$ elevated $\mathrm{CO}_{2}$, warmed; $c t$ $i$ ambient $\mathrm{CO}_{2}$, unwarmed, irrigated plots. Values are means of five replicates with standard errors. $p$ value for irrigation from $t$ test (ct vs ct-i); $p$ value for $\mathrm{CO}_{2}$ from two-factor ANOVA $\left(\mathrm{CO}_{2}\right.$ and warming)

2011), when it reached values of up to four times those during the rest of the year (Fig. 3a). Root production responded to experimental treatments only at the $0-15 \mathrm{~cm}$ depth (Fig. 3a), where elevated $\mathrm{CO}_{2}$ increased root production during most periods, although mainly under ambient temperature conditions when it was often doubled (significant $\mathrm{CO}_{2} \times$ warming interaction; Fig. 3a). Irrigation also increased root production relative to the control conditions (Fig. 3a). As with production, root disappearance was dependent on time, but was more evenly distributed across seasons. Highest disappearance was observed around June-September in 2009, but no clear trend was detected in 2010 (Fig. 3b). Warming increased disappearance around the end of the growing season in 2009 (Fig. 3b; also the case in deeper roots, Fig S2). Although elevated $\mathrm{CO}_{2}$ also interacted significantly with time to influence disappearance, no clear trend was evident.

Fine root litter mass loss

Mass loss for $H$. comata root litter occurred significantly faster than for $B$. gracilis: on average, after 3 years of decomposition, 46 and $52 \%$ of ash free dry mass remained in the bags, respectively (Fig. 4a, b). The average mass loss rate constant $\left(k_{\mathrm{m}}\right)$ was 0.32 year $^{-1}$ for $H$. comata and 0.24 year $^{-1}$ for $B$. gracilis; as a result, there was a significant effect of species on mass loss rate constants (Table 2). Warming had no detectable effect on $k_{\mathrm{m}}$ (Fig. $4 \mathrm{a}$, b; Table 2). Elevated $\mathrm{CO}_{2}$ significantly accelerated decomposition by an average of $10 \%$ (increased $k_{\mathrm{m}}$ ) and this effect appeared stronger for $H$. comata root litter, although 

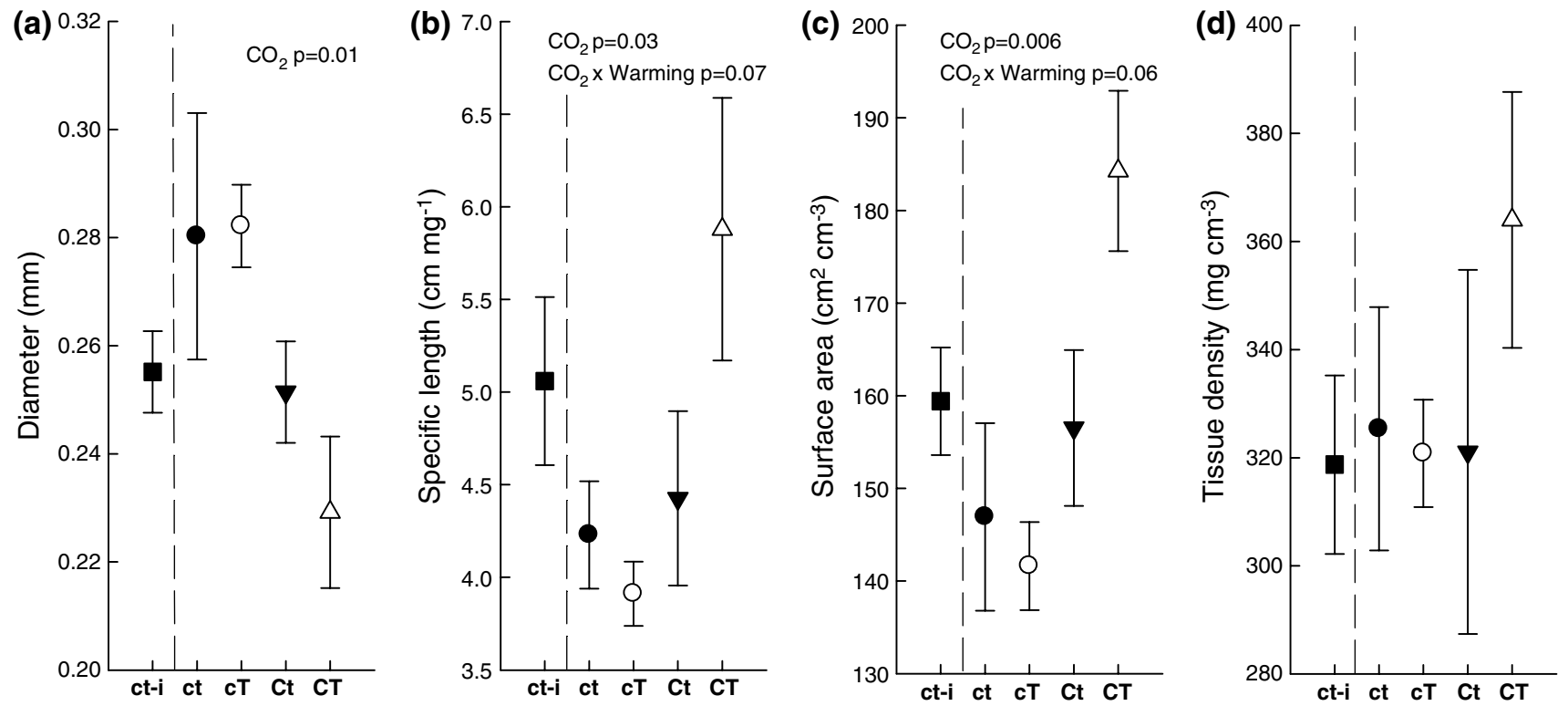

Fig. 2 Average fine root diameter (a), specific root length (b), surface area (c) and tissue density (d) at PHACE in 2010 after five seasons of elevated $\mathrm{CO}_{2}$ and four of warming. All parameters measured at the time of peak biomass. $c t$ ambient $\mathrm{CO}_{2}$, unwarmed; $c T$ ambi-

ent $\mathrm{CO}_{2}$, warmed; $C t$ elevated $\mathrm{CO}_{2}$, unwarmed; $C T$ elevated $\mathrm{CO}_{2}$, warmed; $c t-i$ ambient $\mathrm{CO}_{2}$, unwarmed, irrigated plots. Values are means of five replicates with standard errors. $p$ values from two-factor ANOVA $\left(\mathrm{CO}_{2}\right.$ and warming $)$

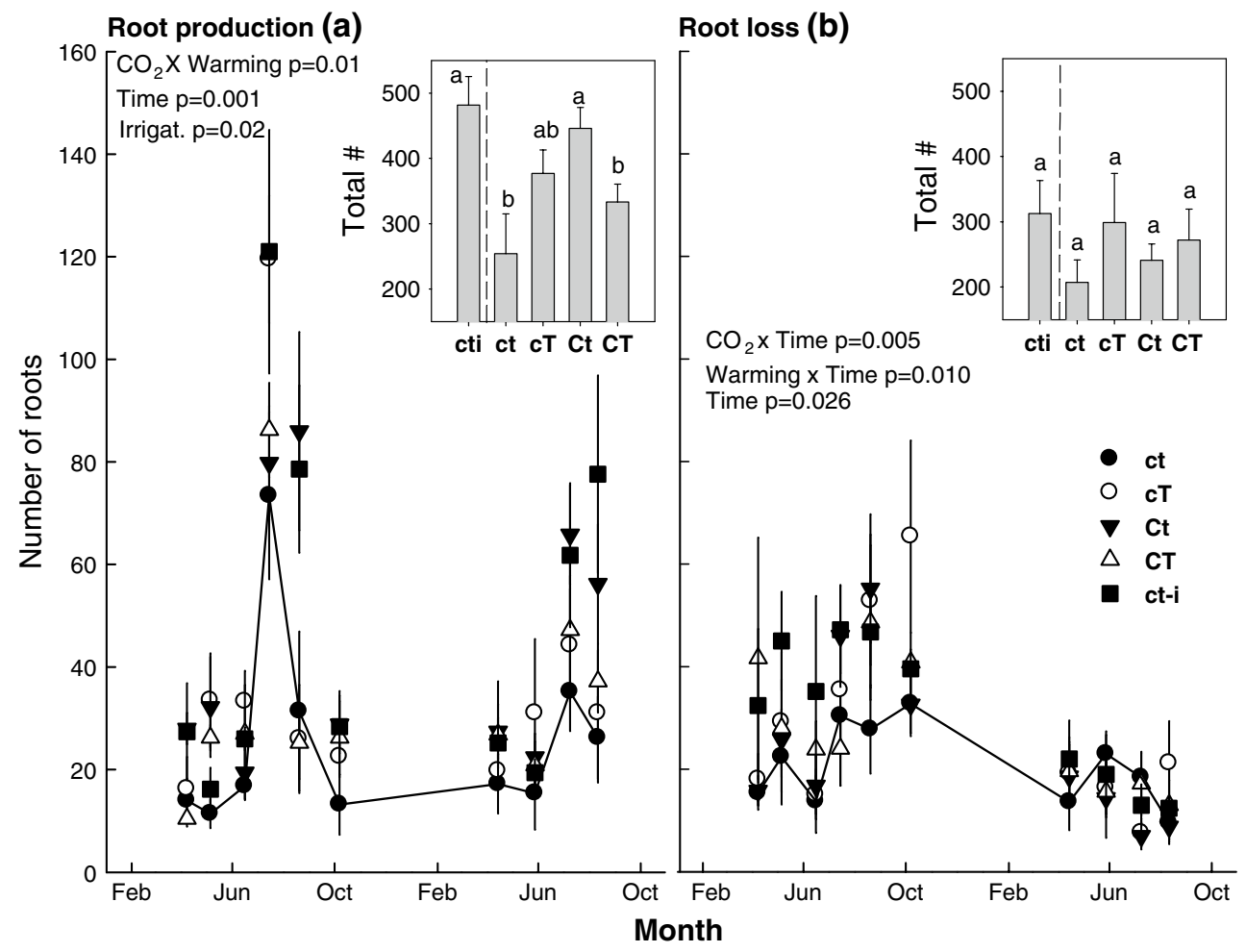

Fig. 3 Number of roots produced (a) and number of roots lost from minirhizotron view (b) over 2009 and 2010 at PHACE. Values over time represent the number produced/lost since the previous observation summed over $0-15 \mathrm{~cm}$ depth. Plotted curve depicts dynamics under ambient conditions. Values in insets represent total cumulative production/loss for the entire period. Same letters indicate no significant difference $(p<0.05)$ using Tuckey HSD mean comparison. $c t$ ambient $\mathrm{CO}_{2}$, unwarmed; $c T$ ambient $\mathrm{CO}_{2}$, warmed; $C t$ elevated $\mathrm{CO}_{2}$, unwarmed; $C T$ elevated $\mathrm{CO}_{2}$, warmed; $c t-i$ ambient $\mathrm{CO}_{2}$, unwarmed, irrigated plots. Values are means of five replicates with standard errors. $p$ values from repeated measures two-factor ANOVA $\left(\mathrm{CO}_{2}\right.$, warming and interaction for main treatments) and one-factor for irrigation (ct vs ct-i; the effect of time was also significant in these analyses, $p$ values not shown) 

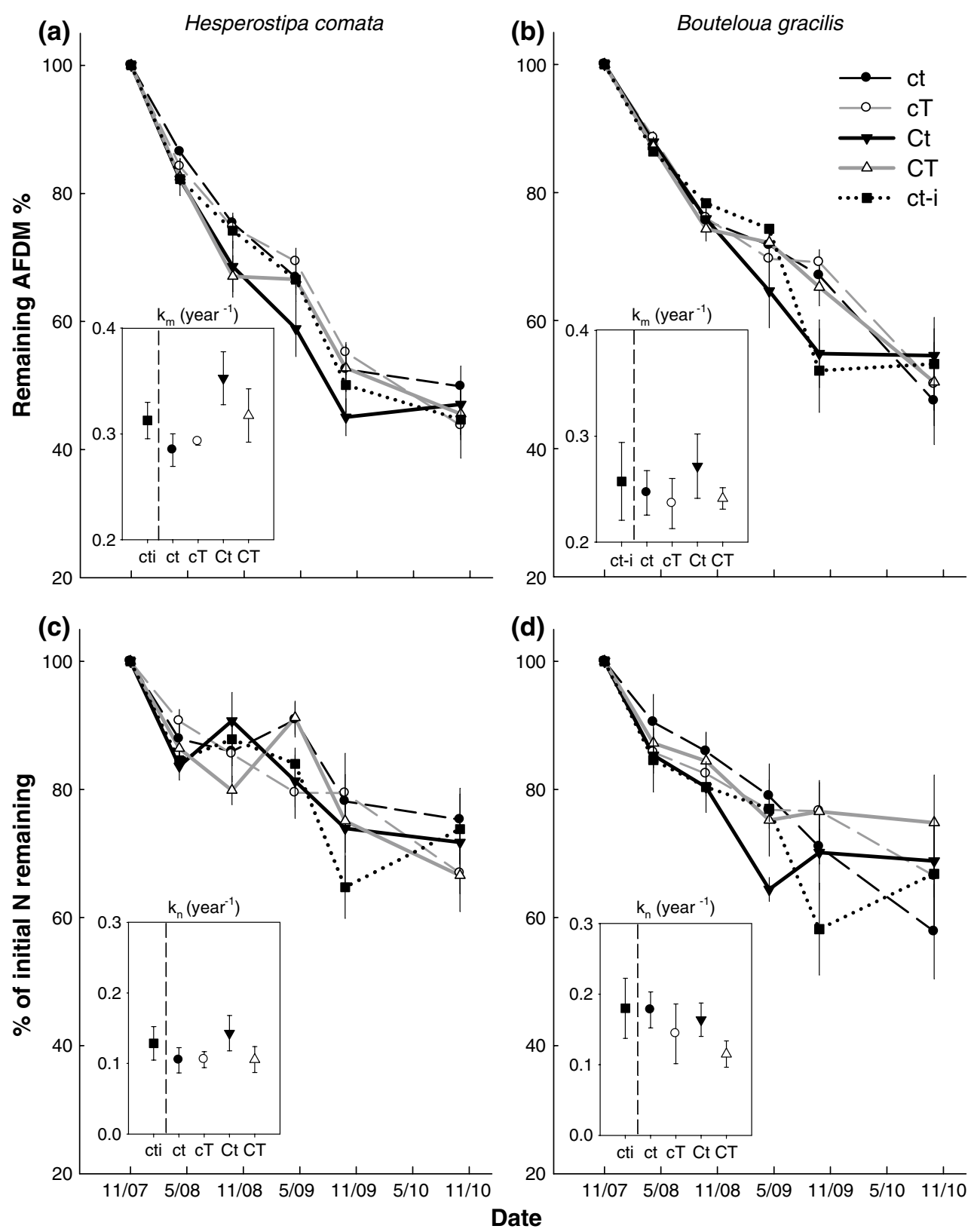

Fig. 4 Percentage of remaining ash-free dry mass (AFDM) and AFDM loss rates ( $k$ ) of Hesperostipa comata (a) and Bouteloua gracilis (b) and percentage of initial $\mathrm{N}$ remaining in ash-free dry mass and $\mathrm{N}$ loss rates $(k)$ of $H$. comata $(\mathbf{c})$ and $B$. gracilis $(\mathbf{d})$ over 3 years of decomposition of buried root litter at PHACE. ct ambient $\mathrm{CO}_{2}$,

unwarmed; $c T$ ambient $\mathrm{CO}_{2}$, warmed; $C t$ elevated $\mathrm{CO}_{2}$, unwarmed; $C T$ elevated $\mathrm{CO}_{2}$, warmed; $c t-i$ ambient $\mathrm{CO}_{2}$, unwarmed, irrigated plots. Values are means of five replicates with standard errors. See Table 2 for statistical tests

no significant interaction was found (Table 2). Irrigation did not have a significant effect on mass loss (Fig. 4a, b; Table 2).

Fine root litter $\mathrm{N}$ dynamics

Initial $\mathrm{N}$ concentration was higher for $H$. comata $(\% \mathrm{~N}=1.20, \mathrm{SD}=0.06)$ than for $B$. gracilis $(\% \mathrm{~N}=0.94$, $\mathrm{SD}=0.04)$. Over the full period of decomposition of both

species, only net release and no net immobilization of $\mathrm{N}$ took place. On average, after 3 years of decomposition, 71 and $67 \%$ of the initial $\mathrm{N}$ content remained in the litter of H. comata and B. gracilis, respectively (Fig. 4c, d), so that the $\mathrm{N}$ loss rate constant $\left(k_{\mathrm{n}}\right)$ was significantly greater for $B$. gracilis than for $H$. comata (Fig. 4c, d; Table 2). There was no effect of warming, $\mathrm{CO}_{2}$ or irrigation on $k_{\mathrm{n}}$ (Table 2). The fraction of $\mathrm{N}$ remaining in litter decreased linearly with mass loss at a rate that was dependent on species and $\mathrm{CO}_{2}$ 
Table 2 Results of ANOVA on the effects of $\mathrm{CO}_{2}$, warming, plant species and irrigation on mass $\left(k_{\mathrm{m}}\right)$ and $\mathrm{N}\left(k_{\mathrm{n}}\right)$ loss rates of buried root litter of Bouteloua gracilis and Hesperostipa comata at PHACE

\begin{tabular}{|c|c|c|c|c|}
\hline & \multicolumn{2}{|c|}{ Mass loss rate $\left(k_{\mathrm{m}}\right)$} & \multicolumn{2}{|c|}{$\begin{array}{l}\mathrm{N} \text { loss rate } \\
\left(k_{\mathrm{n}}\right)\end{array}$} \\
\hline & $F$ & $p$ & $F$ & $p$ \\
\hline \multicolumn{5}{|l|}{ ANOVA } \\
\hline \multicolumn{5}{|l|}{ Source of variation } \\
\hline Species & 24.8 & $<0.0001$ & 4.2 & 0.05 \\
\hline $\mathrm{CO}_{2}$ & 7.1 & 0.01 & 0.0 & 1.0 \\
\hline Warming & 0.6 & 0.5 & 3.0 & 0.09 \\
\hline Species $\times \mathrm{CO}_{2}$ & 2.5 & 0.1 & 1.4 & 0.2 \\
\hline Species $\times$ warming & 0.5 & 0.5 & 0.5 & 0.5 \\
\hline $\mathrm{CO}_{2} \times$ warming & 0.5 & 0.5 & 0.6 & 0.5 \\
\hline Species $\times \mathrm{CO}_{2} \times$ warming & 0.0 & 1.0 & 0.1 & 0.7 \\
\hline \multicolumn{5}{|l|}{ ANOVA irrigation } \\
\hline \multicolumn{5}{|l|}{ Source of variation } \\
\hline Species & 14.0 & 0.002 & 4.6 & 0.04 \\
\hline Irrigation & 0.01 & 0.9 & 0.2 & 0.7 \\
\hline Species $\times$ irrigation & 2.4 & 0.2 & 0.1 & 0.7 \\
\hline
\end{tabular}

Degrees of freedom: 1 for each of the sources of variation, and 31 and 15 for the error in the main and irrigation ANOVA, respectively

$p$ values in bold are considered significant

(interactive effect $\mathrm{CO}_{2} \times$ species $\times$ mass loss; Table 3; Fig. S3). That is, when accounting for the expected variation in $\mathrm{N}$ remaining due to mass loss, $B$. gracilis litter decomposing under elevated $\mathrm{CO}_{2}$ lost $\mathrm{N}$ at a slower rate than under ambient conditions, while for $\mathrm{H}$. comata, the rate slightly increased under elevated $\mathrm{CO}_{2}$ (average $\% \mathrm{~N}$ lost per unit of mass loss: 0.79 and 0.62 for $B$. gracilis litter and 0.48 and 0.55 for $H$. comata litter under ambient and elevated $\mathrm{CO}_{2}$, respectively; Table 3; interactive effect of $\mathrm{CO}_{2} \times$ mass loss in ANCOVA for B. gracilis, $p=0.03$ ). Irrigation did not affect the decrease in remaining $\mathrm{N}$ with mass loss $(p>0.05$ in ANCOVA).

\section{Discussion}

Despite variable responses across years of the aboveground biomass, including positive and neutral effects of $\mathrm{CO}_{2}$ (Morgan et al. 2011), after five seasons of elevated $\mathrm{CO}_{2}-$ when ca. 70-80\% of the biomass had been replaced-root standing mass clearly had increased with elevated $\mathrm{CO}_{2}$, independent of the warming treatment. This observation is consistent with the trajectory of the aboveground biomass observed in previous years (Morgan et al. 2011). This effect is often attributed to increased production (Wang et al. 2012). As hypothesised, root production was significantly greater under $\mathrm{Ct}$ during most periods and cumulatively, and greater during most periods under CT compared to the control (although not significantly overall), suggesting that root production was stimulated by elevated $\mathrm{CO}_{2}$ (de Graaff et al. 2006, Milchunas et al. 2005). However, the increase in production under $\mathrm{Ct}(75 \%)$ was not matched by an equivalent increase in root disappearance (21\%) (insets in Fig. 3), suggesting a reduction in "per capita" loss, i.e. the fraction of produced roots that were lost-as opposed to a net reduction in disappearance. These findings for a semi-arid grassland contrast with observations in mesic grasslands where no changes in production or loss with elevated $\mathrm{CO}_{2}$ were observed (Arnone et al. 2000; Pilon et al. 2013) or where increases in production were matched by increases in loss (Fitter et al. 1996). Thus, our observations suggest that greater root standing mass under CT resulted mainly from increased production, whereas those under $\mathrm{Ct}$ resulted from both increased production and reduced per-capita root disappearance.

As hypothesised, elevated $\mathrm{CO}_{2}$ and warming (CT) had important synergistic impacts on root production and morphology. Roots under CT were longer (per unit of mass and in total), thinner, and had greater surface area relative to the control or Ct (Fig. 2). Although standing masses were equivalent under $\mathrm{Ct}$ and $\mathrm{CT}$, under $\mathrm{CT}$ the positive effect of elevated $\mathrm{CO}_{2}$ on the number of roots produced was partially suppressed by warming (Fig. 3a). Fewer roots produced under $\mathrm{CT}$ than $\mathrm{Ct}$ which had more length and were denser (although not significantly) could have resulted in similar standing mass pools as in the Ct plots. Our observations thus suggest that expected future warmer and elevated $\mathrm{CO}_{2}$ conditions may generate roots that will differ in function and dynamics, beyond the sole impacts of their greater biomass. For example longer, thinner roots with higher surface area should decay faster (Gartner and Cardon 2004; Gillon et al. 1994). Also, greater specific root length and root surface area, combined with a greater overall biomass pool, should enhance rhizosphere-mediated processes such as priming of soil organic matter (Kuzyakov 2010). The clear impact of future conditions on this grassland's root morphology highlights the need to directly assess root morphology-mediated impacts of climate change.

Community level morphological changes, particularly thinner, longer roots could have resulted from increased soil exploration for water, as a response to desiccation with warming, and for nutrients with elevated $\mathrm{CO}_{2}$ (Zak et al. 2011), where $\mathrm{N}$ availability decreased. However, shifts in plant community composition probably also played a role in these responses. By the fourth season of elevated $\mathrm{CO}_{2}$, the combination of elevated $\mathrm{CO}_{2}$ and warming had favoured the growth of the dominant $\mathrm{C}_{4}$ grass studied here (Morgan et al. 2011), which is characterised by a profusely branched laterally extending system of very fine roots (Weaver 1920). 
Table 3 Percentage of original N remaining as a linear function of mass loss over 3 years of decomposition of buried root litter and results from ANCOVA on percentage $\mathrm{N}$ remaining

\begin{tabular}{|c|c|c|c|c|}
\hline Species & Treatment & \multicolumn{2}{|l|}{ Equation } & $r^{2}$ \\
\hline B. gracilis & $\mathrm{ct}-\mathrm{i}$ & \multicolumn{2}{|c|}{$\% \mathrm{~N}$ remaining $=99.0-0.82 \times \%$ mass loss } & 0.82 \\
\hline & ct & \multicolumn{2}{|c|}{$\% \mathrm{~N}$ remaining $=101.6-0.83 \times \%$ mass loss } & 0.84 \\
\hline & $\mathrm{cT}$ & \multicolumn{2}{|c|}{$\% \mathrm{~N}$ remaining $=99.6-0.75 \times \%$ mass loss } & 0.75 \\
\hline & $\mathrm{Ct}$ & \multicolumn{2}{|c|}{$\% \mathrm{~N}$ remaining $=96.1-0.66 \times \%$ mass loss } & 0.75 \\
\hline & $\mathrm{CT}$ & \multicolumn{2}{|c|}{$\% \mathrm{~N}$ remaining $=97.7-0.58 \times \%$ mass loss } & 0.63 \\
\hline \multirow[t]{5}{*}{ H. comata } & ct-i & \multicolumn{2}{|c|}{$\% \mathrm{~N}$ remaining $=100.8-0.59 \times \%$ mass loss } & 0.82 \\
\hline & ct & \multicolumn{2}{|c|}{$\% \mathrm{~N}$ remaining $=99.0-0.47 \times \%$ mass loss } & 0.71 \\
\hline & $\mathrm{cT}$ & \multicolumn{2}{|c|}{$\% \mathrm{~N}$ remaining $=100.6-0.48 \times \%$ mass loss } & 0.74 \\
\hline & $\mathrm{Ct}$ & \multicolumn{2}{|c|}{$\% \mathrm{~N}$ remaining $=101.5-0.61 \times \%$ mass loss } & 0.74 \\
\hline & $\mathrm{CT}$ & \multicolumn{2}{|c|}{$\% \mathrm{~N}$ remaining $=98.7-0.48 \times \%$ mass loss } & 0.58 \\
\hline \multicolumn{2}{|c|}{ Source of variation } & $F$ ratio & Prob $>F$ & \\
\hline \multicolumn{5}{|l|}{ ANCOVA } \\
\hline \multicolumn{2}{|l|}{ Species } & 52.0 & $<0.0001$ & \\
\hline \multicolumn{2}{|l|}{$\mathrm{CO}_{2}$} & 0.2 & 0.655 & \\
\hline \multicolumn{2}{|l|}{ Warming } & 2.8 & 0.098 & \\
\hline \multicolumn{2}{|c|}{$\%$ mass loss } & 582.3 & $<0.0001$ & \\
\hline \multicolumn{2}{|c|}{ Species $\times \mathrm{CO}_{2}$} & 2.0 & 0.163 & \\
\hline \multicolumn{2}{|c|}{ Species $\times$ warming } & 0.3 & 0.596 & \\
\hline \multicolumn{2}{|c|}{$\mathrm{CO}_{2} \times$ warming } & 0.6 & 0.433 & \\
\hline \multicolumn{2}{|c|}{ Species $\times \mathrm{CO}_{2} \times$ warming } & 1.3 & 0.260 & \\
\hline \multicolumn{2}{|c|}{ Species $\times \%$ mass loss } & 15.0 & 0.0001 & \\
\hline \multicolumn{2}{|c|}{$\mathrm{CO}_{2} \times \%$ mass loss } & 0.8 & 0.359 & \\
\hline \multicolumn{2}{|c|}{ Species $\times \mathrm{CO}_{2} \times \%$ mass loss } & 5.7 & 0.018 & \\
\hline \multicolumn{2}{|c|}{ Warming $\times \%$ mass loss } & 1.9 & 0.167 & \\
\hline \multicolumn{2}{|c|}{ Species $\times$ warming $\times \%$ mass loss } & 0.0 & 0.846 & \\
\hline \multicolumn{2}{|c|}{$\mathrm{CO}_{2} \times$ warming $\times \%$ mass loss } & 0.4 & 0.513 & \\
\hline \multicolumn{2}{|c|}{ Species $\times \mathrm{CO}_{2} \times$ warming $\times \%$ mass loss } & 0.5 & 0.494 & \\
\hline
\end{tabular}

Bold values indicate statistical significance at $p$ values

$c t$ ambient $\mathrm{CO}_{2}$, unwarmed; $c T$ ambient $\mathrm{CO}_{2}$, warmed; $C t$ elevated $\mathrm{CO}_{2}$, unwarmed; $C T$ elevated $\mathrm{CO}_{2}$, warmed; $c t-i$ ambient $\mathrm{CO}_{2}$, unwarmed, irrigated plots. ANCOVA results presented are for main treatments and their interaction, degrees of freedom $=1$ in all tests

Our observation that elevated $\mathrm{CO}_{2}$ increased mass loss rates independent of warming treatment is contrary to expectations, and suggests that its impacts on the soil environment enhanced root decomposition. Greater mass loss rates in this water-limited system may be partly explained by the increase in soil moisture with elevated $\mathrm{CO}_{2}$ (Bontti et al. 2009). While impacts of the irrigation treatment should be interpreted with care as greater moisture due to water addition is not fully equivalent to lower water loss with lower transpiration, the lack of a detectable impact of irrigation on mass loss, suggests that moisture was not the principal factor responsible for accelerated mass loss under elevated $\mathrm{CO}_{2}$. Soil labile $\mathrm{C}$ availability may have played a role in the response of decomposition as it can enhance mass loss (de Graaff et al. 2010) and we have detected increases in the labile $\mathrm{C}$ pool with elevated $\mathrm{CO}_{2}$ at PHACE (Carrillo et al. 2011). The absence of a warming effect on mass loss could be explained by enhanced decomposition with higher temperatures being counteracted by reduced decomposition with desiccation (Cheng et al. 2010). It also supports the expectation that higher temperatures will only increase decomposition in grasslands when water limitation is not present (Bontti et al. 2009). The positive effect of $\mathrm{CO}_{2}$ on decomposition concomitant with reduced percapita disappearance, which encompasses both death and decomposition, suggests a decoupling of the latter two processes. Therefore, changes in root disappearance of roots in rhizotron images should not be interpreted simply as corresponding changes in mortality-commonly done in the literature-as they may instead be driven by decomposition. 
Combining minirizotron observations with concurrent direct measurements of standing stocks and mass loss has the potential to improve our insight into root dynamics.

We observed increased mass loss with elevated $\mathrm{CO}_{2}$ in both species studied, which together comprise over $50 \%$ of the aboveground biomass in this system, suggesting that fine root decomposition at the ecosystem scale is likely to respond positively to increased $\mathrm{CO}_{2}$. Because we measured decomposition of common root material within the plots, it does not include effects mediated by root chemistry or morphology. We anticipate that the observed increase in decomposition due to the soil environment will not be strongly influenced by root chemistry, but is likely to be enhanced by changes in root morphology, as found in a comparison of switchgrass cultivars (de Graaff et al. 2013). As noted above, longer thinner roots, with more surface area under elevated $\mathrm{CO}_{2}$ and warming are expected to enhance decomposition rates, and therefore our decomposition rates under elevated $\mathrm{CO}_{2}$ may have been underestimated. However, it is unlikely that direct impacts of changes in litter chemistry would be a major driver of long-term mass loss in this system (Norby et al. 2001). In other systems, most experiments have not detected root chemistry-mediated effects of $\mathrm{CO}_{2}$ on decomposition (Allard et al. 2004; Chapman et al. 2005; de Graaff et al. 2011; Dilustro et al. 2001; King et al. 2005; Van Vuuren et al. 2000) while some have detected modest decreases (Gorissen and Cotrufo 2000; Gorissen et al. 1995; Lutze et al. 2000). Moreover, the latter results were mostly observed in laboratory studies and during early-stage decomposition when $\mathrm{N}$ concentration is the main factor driving decay (Berg and McClaugherty 2003).

Some studies have suggested that increased decomposition with elevated $\mathrm{CO}_{2}$ can offset the effects of increased $\mathrm{C}$ inputs with greater biomass, thus leading to no net accumulation of soil C (Sindhoj et al. 2000; Xie et al. 2005). PHACE modelling predictions by Parton et al. (2007b) showed a gradual decrease of soil $\mathrm{C}$ with elevated $\mathrm{CO}_{2}$ despite increased production, due to more rapid decomposition. Our observations of enhanced mass loss are consistent with ecosystem-level $\mathrm{C}$ exchange measurements indicating net $\mathrm{C}$ loss with elevated $\mathrm{CO}_{2}$ (Pendall et al. 2013). In addition, there are no indications of increases in the total or resistant soil organic $\mathrm{C}$ at PHACE with elevated $\mathrm{CO}_{2}$ (Carrillo et al. 2011 and recent unpublished data), despite greater production. Together with these, our results suggest increased root mass loss, due to changes in soil environmental conditions, has contributed to the net ecosystem $\mathrm{C}$ loss, and support the prediction that increased decomposition will tend to offset greater $\mathrm{C}$ inputs as $\mathrm{CO}_{2}$ concentrations rise.

When comparing the dynamics of the fraction of $\mathrm{N}$ remaining as a function of mass loss (Berg and McClaugherty 2003; Parton et al. 2007a), we observed that net $\mathrm{N}$ retention in $B$. gracilis litter (the $\mathrm{C}_{4}$ species with the lowest $\mathrm{N}$ concentration) was increased by the soil environmental conditions present under elevated $\mathrm{CO}_{2}$, particularly when combined with warming. Greater net $\mathrm{N}$ retention could have been caused by increased $\mathrm{N}$ accrual and/or decreased release. Increased accrual would be consistent with reduced $\mathrm{N}$ availability in soil as detected via resin probes. Dilustro et al. (2001) attributed increased accrual in litter to greater microbial $\mathrm{N}$ demand under elevated $\mathrm{CO}_{2}$, consistent with higher overall microbial demand under elevated $\mathrm{CO}_{2}$ at PHACE (Dijkstra et al. 2010). Given the dominance of this $\mathrm{C}_{4}$ grass and evidence that suggests it will remain competitive under future conditions (Morgan et al. 2011), greater retention of $\mathrm{N}$ in its decomposing litter has the potential to alter soil $\mathrm{N}$ availability. Increased $\mathrm{N}$ retention concurrent with greater mass loss with elevated $\mathrm{CO}_{2}$ provides an example of species-level decoupling of $\mathrm{C}$ and $\mathrm{N}$ cycling of belowground litter resulting from climate change, and presents the question of whether or not this is a common response across species and ecosystems.

The impact of climate change on root dynamics and the cycling of $\mathrm{C}$ and nutrients from roots to soil will occur via multiple, simultaneous and difficult-to-observe processes. Our multifaceted approach evaluating standing root mass, residence time, production, disappearance, decomposition and morphology provided important insights into the complex belowground responses of the native North American mixed-grass prairie to anticipated climate conditions. Our findings place the turnover of the fine roots in the native mixed-grass prairie among the lowest for temperate grasslands (Gill and Jackson 2000). In contrast to mesic grasslands, in this semiarid grassland elevated $\mathrm{CO}_{2}$ increased fine root standing mass by both increasing production and decreasing per-capita disappearance. We found that elevated $\mathrm{CO}_{2}$, particularly in combination with warming, produced roots with distinctive morphological traits that could potentially lead to enhanced decay rates and rhizospheremediated soil organic matter decomposition. These observations highlight the importance of morphology-mediated impacts of climate change and of 'looking beyond' the biomass. Root litter decomposition increased in the soil environmental conditions generated by elevated $\mathrm{CO}_{2}$, but not in those generated by warming, likely due to the waterlimited nature of this system and the desiccation generated by warming. Thus, while we cannot be sure how future climate's impact on the soil physicochemical environment, litter chemistry, plant community and morphology together will affect root decomposition, we hypothesise that they will tend to increase decomposition and limit the future net soil $\mathrm{C}$ accrual expected from greater root standing mass. Our observations also suggest that increased $\mathrm{N}$ retention in decomposing litter of some species under elevated $\mathrm{CO}_{2}$ could alter $\mathrm{N}$ availability in the mineral soil, through 
treatment effects on species composition with potential ecosystem-scale impacts. The strong collection of medium/ long-term field data on the responses of grassland roots to individual and combined climate change factors presented here should also be of value for ongoing and future modelling efforts.

Acknowledgments We thank David Smith, Erik Hardy and Matthew Parsons for their technical assistance and Joanne Newcomb, Jennifer Bell, Hannah Munn, Courtney Ellis, Christine Rumsey, Jana Heisler-White, Sun Wei, Lyndsy Soltau, Lindsay Ross, Lana MacDonald, Janet Chen for assistance in the field and in the laboratory. This material is based upon work supported by the National Science Foundation (Grant no. 1021559 DEB), USDA-CSREES Soil Processes Program (Grant no. 2008-35107-18655), the US Department of Energy's Office of Science (BER) through the Terrestrial Ecosystem Science program, the Western Regional Center of the National Institute for Climatic Change Research at Northern Arizona University, and by the Australian Research Council (FT100100779).

\section{References}

Adair EC, Parton WJ, Del Grosso SJ et al (2008) Simple three-pool model accurately describes patterns of long-term litter decomposition in diverse climates. Glob Change Biol 14:2636-2660

Aerts R (2006) The freezer defrosting: global warming and litter decomposition rates in cold biomes. J Ecol 94(4):713-724

Allard V, Newton PCD, Lieffering M, Soussana JF, Grieu P, Matthew $\mathrm{C}$ (2004) Elevated $\mathrm{CO}_{2}$ effects on decomposition processes in a grazed grassland. Glob Change Biol 10:1553-1564

Allard V, Newton PCD, Lieffering M, Soussana JF, Carran RA, Matthew C (2005) Increased quantity and quality of coarse soil organic matter fraction at elevated $\mathrm{CO}_{2}$ in a grazed grassland are a consequence of enhanced root growth rate and turnover. Plant Soil 276:49-60

Anderson LJ, Derner JD, Polley HW, Gordon WS, Eissenstat DM, Jackson RB (2010) Root responses along a subambient to elevated $\mathrm{CO}_{2}$ gradient in a $\mathrm{C} 3-\mathrm{C} 4$ grassland. Glob Change Biol 16:454-468

Arnone JA, Zaller JG, Spehn EM, Niklaus PA, Wells CE, Korner C (2000) Dynamics of root systems in native grasslands: effects of elevated atmospheric $\mathrm{CO}_{2}$. New Phytol 147:73-86

Bai WM, Wan SQ, Niu SL et al (2010) Increased temperature and precipitation interact to affect root production, mortality, and turnover in a temperate steppe: implications for ecosystem $\mathrm{C}$ cycling. Glob Change Biol 16:1306-1316

Berg B, Mcclaugherty C (2003) Plant litter: decomposition, humus formation, carbon sequestration. Springer, Berlin

Bjork RG, Majdi H, Klemedtsson L, Lewis-Jonsson L, Molau U (2007) Long-term warming effects on root morphology, root mass distribution, and microbial activity in two dry tundra plant communities in northern Sweden. New Phytol 176:862-873

Bontti EE, Decant JP, Munson SM et al (2009) Litter decomposition in grasslands of Central North America (US Great Plains). Glob Change Biol 15:1356-1363

Carrillo Y, Pendall E, Dijkstra FA, Morgan JA, Newcomb JM (2011) Response of soil organic matter pools to elevated $\mathrm{CO}_{2}$ and warming in a semi-arid grassland. Plant Soil 347:339-350

Carrillo Y, Dijkstra F, Pendall E, Morgan J, Blumenthal D (2012) Controls over soil nitrogen pools in a semiarid grassland under elevated $\mathrm{CO}_{2}$ and warming. Ecosystems 15:761-774
Chapman JA, King JS, Pregitzer KS, Zak DR (2005) Effects of elevated concentrations of atmospheric $\mathrm{CO}_{2}$ and tropospheric $\mathrm{O}_{3}$ on decomposition of fine roots. Tree Physiol 25:1501-1510

Cheng XL, Luo YQ, Su B et al (2010) Experimental warming and clipping altered litter carbon and nitrogen dynamics in a tallgrass prairie. Agric Ecosyst Environ 138:206-213

Coleman DC, DA Crossley J, Hendrix PF (2004) Fundamentals of soil ecology, 2nd edn. Elsevier Publishing, San Diego

Crow SE, Lajtha K, Filley TR, Swanston CW, Bowden RD, Caldwell BA (2009) Sources of plant-derived carbon and stability of organic matter in soil: implications for global change. Glob Change Biol 15:2003-2019

De Boeck HJ, Lemmens C, Zavalloni C et al (2008) Biomass production in experimental grasslands of different species richness during three years of climate warming. Biogeosciences 5:585-594

De Graaff MA, Van Groenigen KJ, Six J, Hungate B, Van Kessel C (2006) Interactions between plant growth and soil nutrient cycling under elevated $\mathrm{CO}_{2}$ : a meta-analysis. Glob Change Biol 12:2077-2091

De Graaff MA, Classen AT, Castro HF, Schadt CW (2010) Labile soil carbon inputs mediate the soil microbial community composition and plant residue decomposition rates. New Phytol 188:1055-1064

De Graaff MA, Schadt CW, Rula K, Six J, Schweitzer JA, Classen AT (2011) Elevated $\mathrm{CO}_{2}$ and plant species diversity interact to slow root decomposition. Soil Biol Biochem 43:2347-2354

De Graaff MA, Six J, Jastrow JD, Schadt CW, Wullschleger SD (2013) Variation in root architecture among switchgrass cultivars impacts root decomposition rates. Soil Biol Biochem 58:198-206

Dijkstra FA, Blumenthal D, Morgan JA, Pendall E, Carrillo Y, Follett RF (2010) Contrasting effects of elevated $\mathrm{CO}_{2}$ and warming on nitrogen cycling in a semiarid grassland. New Phytol 187:426437. doi:10.1111/j.1469-8137.2010.03293.x

Dijkstra FA, Pendall E, Morgan JA et al (2012) Climate change alters stoichiometry of phosphorus and nitrogen in a semiarid grassland. New Phytol 196:807-815

Dilustro JJ, Day FP, Drake BG (2001) Effects of elevated atmospheric $\mathrm{CO}_{2}$ on root decomposition in a scrub oak ecosystem. Glob Change Biol 7:581-589

Eissenstat DM, Wells CE, Yanai RD, Whitbeck JL (2000) Building roots in a changing environment: implications for root longevity. New Phytol 147:33-42

Fitter AH, Self GK, Wolfenden J et al (1996) Root production and mortality under elevated atmospheric carbon dioxide. Plant Soil 187:299-306

Fitter AH, Self GK, Brown TK, Bogie DS, Graves JD, Benham D, Ineson $P$ (1999) Root production and turnover in an upland grassland subjected to artificial soil warming respond to radiation flux and nutrients, not temperature. Oecologia 120:575-581

Garcia-Pausas J, Casals P, Rovira P, Vallecillo S, Sebastia MT, Romanya $J$ (2012) Decomposition of labelled roots and root-C and $-\mathrm{N}$ allocation between soil fractions in mountain grasslands. Soil Biol Biochem 49:61-69

Gartner TB, Cardon ZG (2004) Decomposition dynamics in mixedspecies leaf litter. Oikos 104:230-246

Gill RA, Jackson RB (2000) Global patterns of root turnover for terrestrial ecosystems. New Phytol 147:13-31

Gillon D, Joffre R, Ibrahima A (1994) Initial litter properties and decay rate: a microcosm experiment on Mediterranean species. Can J Bot 72:946-954

Gorissen A, Cotrufo MF (2000) Decomposition of leaf and root tissue of three perennial grass species grown at two levels of atmospheric $\mathrm{CO}_{2}$ and $\mathrm{N}$ supply. Plant Soil 224:75-84

Gorissen A, Vanginkel JH, Keurentjes JJB, Vanveen JA (1995) Grass root decomposition is retarded when grass has been grown under elevated $\mathrm{CO}_{2}$. Soil Biol Biochem 27:117-120 
Harmon ME, Silver WL, Fasth B, Chen H, Burke IC, Parton WJ, Hart SC, Currie WS, Lidet (2009) Long-term patterns of mass loss during the decomposition of leaf and fine root litter: an intersite comparison. Glob Change Biol 15:1320-1338

Hobbie SE, Oleksyn J, Eissenstat DM, Reich PB (2010) Fine root decomposition rates do not mirror those of leaf litter among temperate tree species. Oecologia 162:505-513

Hui DF, Jackson RB (2006) Geographical and interannual variability in biomass partitioning in grassland ecosystems: a synthesis of field data. New Phytol 169:85-93

Jackson RB, Canadell J, Ehleringer JR, Mooney HA, Sala OE, Schulze ED (1996) A global analysis of root distributions for terrestrial biomes. Oecologia 108:389-411

Jackson RB, Mooney HA, Schulze ED (1997) A global budget for fine root biomass, surface area, and nutrient contents. Proc Natl Acad Sci USA 94:7362-7366

Jones MB, Donnelly A (2004) Carbon sequestration in temperate grassland ecosystems and the influence of management, climate and elevated $\mathrm{CO}_{2}$. New Phytol 164:423-439

Kimball BA, Conley MM, Wang S, Lin X, Luo C, Morgan J, Smith D (2008) Infrared heater arrays for warming ecosystem field plots. Glob Change Biol 14:309-320

King JS, Pregitzer KS, Zak DR, Holmes WE, Schmidt K (2005) Fine root chemistry and decomposition in model communities of north-temperate tree species show little response to elevated atmospheric $\mathrm{CO}_{2}$ and varying soil resource availability. Oecologia 146:318-328

Klumpp K, Soussana JF (2009) Using functional traits to predict grassland ecosystem change: a mathematical test of the responseand-effect trait approach. Glob Change Biol 15:2921-2934

Kuzyakov Y (2010) Priming effects: interactions between living and dead organic matter. Soil Biol Biochem 42:1363-1371

LeCain DR, Morgan JA, Milchunas DG, Mosier AR, Nelson JA, Smith DP (2006) Root biomass of individual species, and root size characteristics after five years of $\mathrm{CO}_{2}$ enrichment on native shortgrass steppe. Plant Soil 279:219-228

Luo Y (2003) Uncertainties in interpretation of isotope signals for estimation of fine root longevity: theoretical considerations. Glob Change Biol 9:1118-1129

Lutze JL, Gifford RM, Adams HN (2000) Litter quality and decomposition in Danthonia richardsonii swards in response to $\mathrm{CO}_{2}$ and nitrogen supply over four years of growth. Glob Change Biol 6:13-24

Miglietta F, Hoosbeek MR, Foot J, Gigon F, Hassinen A, Heijmans M, Peressotti A, Saarinen T, van Breemen N, Wallen B (2001) Spatial and temporal performance of the MiniFACE (Free Air $\mathrm{CO}_{2}$ Enrichment) system on bog ecosystems in northern and central Europe. Environ Monit Assess 66:107-127

Milchunas DG (2009) Estimating root production: comparison of 11 methods in shortgrass steppe and review of biases. Ecosystems 12:1381-1402

Milchunas DG, Morgan JA, Mosier AR, LeCain DR (2005) Root dynamics and demography in shortgrass steppe under elevated $\mathrm{CO}_{2}$, and comments on minirhizotron methodology. Glob Change Biol 11:1837-1855

Morgan JA, Lecain DR, Pendall E et al (2011) C4 grasses prosper as carbon dioxide eliminates desiccation in warmed semi-arid grassland. Nature 476:202-205

Nie M, Pendall E, Bell C, Gasch CK, Raut S, Tamang S, Wallenstein MD (2013) Positive climate feedbacks of soil microbial communities in a semi-arid grassland. Ecol Lett 16:234-241

NOAA (1994) Local climatological data, Cheyenne, Wyoming, Ashville, NC, National Climate Data Center
Norby RJ, Jackson RB (2000) Root dynamics and global change: seeking an ecosystem perspective. New Phytol 147:3-12

Norby RJ, Cotrufo MF, Ineson P, O'neill EG, Canadell JG (2001) Elevated $\mathrm{CO}_{2}$, litter chemistry, and decomposition: a synthesis. Oecologia 127:153-165

Ostonen I, Puttsepp U, Biel C et al (2007) Specific root length as an indicator of environmental change. Plant Biosyst 141:426-442

Parton W, Silver WL, Burke IC et al (2007a) Global-scale similarities in nitrogen release patterns during long-term decomposition. Science 315:361-364

Parton WJ, Morgan JA, Wang GM, Del Grosso S (2007b) Projected ecosystem impact of the Prairie Heating and $\mathrm{CO}_{2}$ enrichment experiment. New Phytol 174:823-834

Pendall E, Mosier AR, Morgan JA (2004) Rhizodeposition stimulated by elevated $\mathrm{CO}_{2}$ in a semiarid grassland. New Phytol 162:447-458

Pendall E, Heisler-White JL, Williams DG, Dijkstra FA, Carrillo Y, Morgan JA, LeCain DR (2013) Warming reduces carbon losses from grassland exposed to elevated atmospheric carbon dioxide. PLoS One 8(8):e71921. doi:10.1371/journal.pone.0071921

Pilon R, Picon-Cochard C, Bloor JMG, Revaillot S, Kuhn E, Falcimagne R, Balandier P, Soussana JF (2013) Grassland root demography responses to multiple climate change drivers depend on root morphology. Plant Soil 364:395-408

Robinson D (2007) Implications of a large global root biomass for carbon sink estimates and for soil carbon dynamics. Proc R Soc B Biol Sci 274:2753-2759

Shaw MR, Zavaleta ES, Chiariello NR, Cleland EE, Mooney HA, Field CB (2002) Grassland responses to global environmental changes suppressed by elevated $\mathrm{CO}_{2}$. Science 298:1987-1990

Sindhoj E, Hansson AC, Andren O, Katterer T, Marissink M, Pettersson R (2000) Root dynamics in a semi-natural grassland in relation to atmospheric carbon dioxide enrichment, soil water and shoot biomass. Plant Soil 223:253-263

Solomon S, Qin D, Manning M et al (eds) (2007) Contribution of working group I to the fourth assessment report of the intergovernmental panel on climate change, New York. Cambridge University Press, Cambridge

Van Vuuren MMI, Robinson D, Scrimgeour CM, Raven JA, Fitter AH (2000) Decomposition of C-13-labelled wheat root systems following growth at different $\mathrm{CO}_{2}$ concentrations. Soil Biol Biochem 32:403-413

Volder A, Gifford RM, Evans JR (2007) Effects of elevated atmospheric $\mathrm{CO}_{2}$, cutting frequency, and differential day/night atmospheric warming on root growth and turnover of Phalaris swards. Glob Change Biol 13:1040-1052

Wan SQ, Norby RJ, Pregitzer KS, Ledford J, O'neill EG (2004) $\mathrm{CO}_{2}$ enrichment and warming of the atmosphere enhance both productivity and mortality of maple tree fine roots. New Phytol $162: 437-446$

Wang D, Heckathorn SA, Wang XZ, Philpott SM (2012) A meta-analysis of plant physiological and growth responses to temperature and elevated $\mathrm{CO}_{2}$. Oecologia 169:1-13

Weaver JE (1920) Root development in the grassland formation, a correlation of the root systems of native vegetation and crop plants, vol 292. Carnegie Inst. Wash., Pub

Xie ZB, Cadisch G, Edwards G, Baggs EM, Blum H (2005) Carbon dynamics in a temperate grassland soil after 9 years exposure to elevated $\mathrm{CO}_{2}$ (Swiss FACE). Soil Biol Biochem 37:1387-1395

Zak DR, Pregitzer KS, Kubiske ME, Burton AJ (2011) Forest productivity under elevated $\mathrm{CO}_{2}$ and $\mathrm{O}_{3}$ : positive feedbacks to soil $\mathrm{N}$ cycling sustain decade-long net primary productivity enhancement by $\mathrm{CO}_{2}$. Ecol Lett 14:1220-1226 


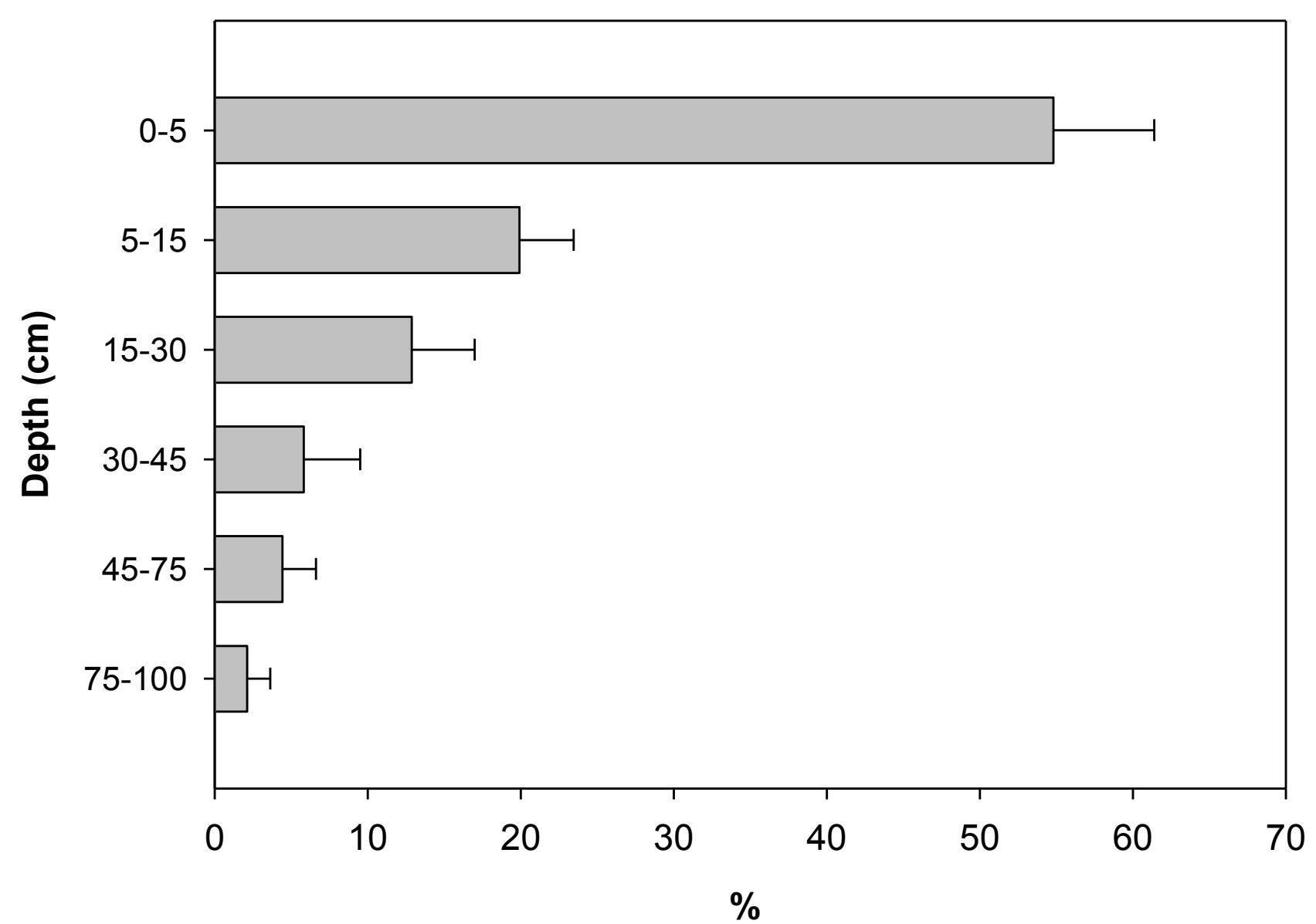

Figure S1. Belowground biomass distribution across depth in the native mixed grass prairie at the PHACE site in 2005, before experimental treatments began. Values are means and standard deviations ( $\mathrm{n}=30$ plots). Values for each plot obtained by compositing three individual soil cores. 
Root production (a)

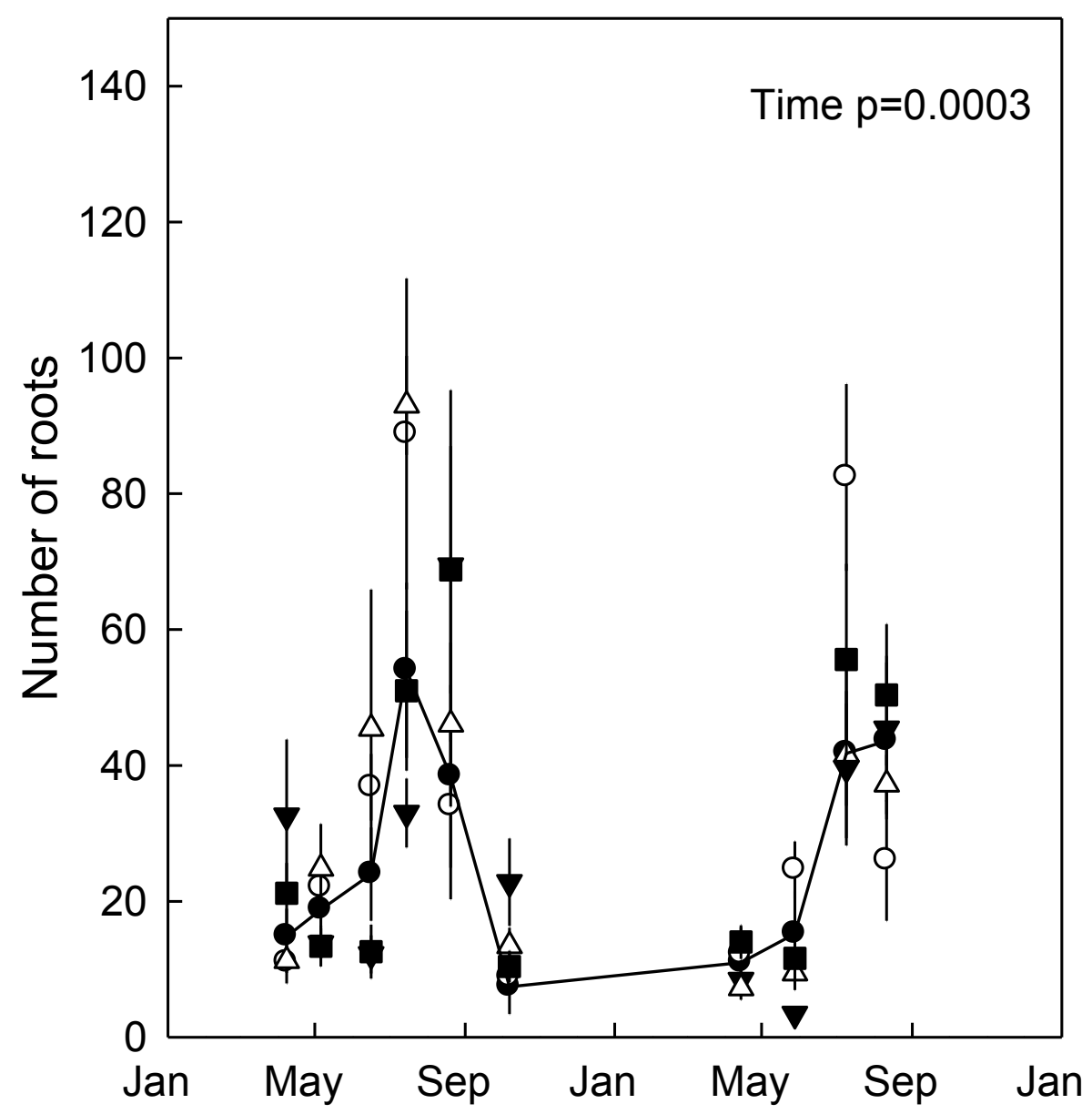

Root disappearance (b)

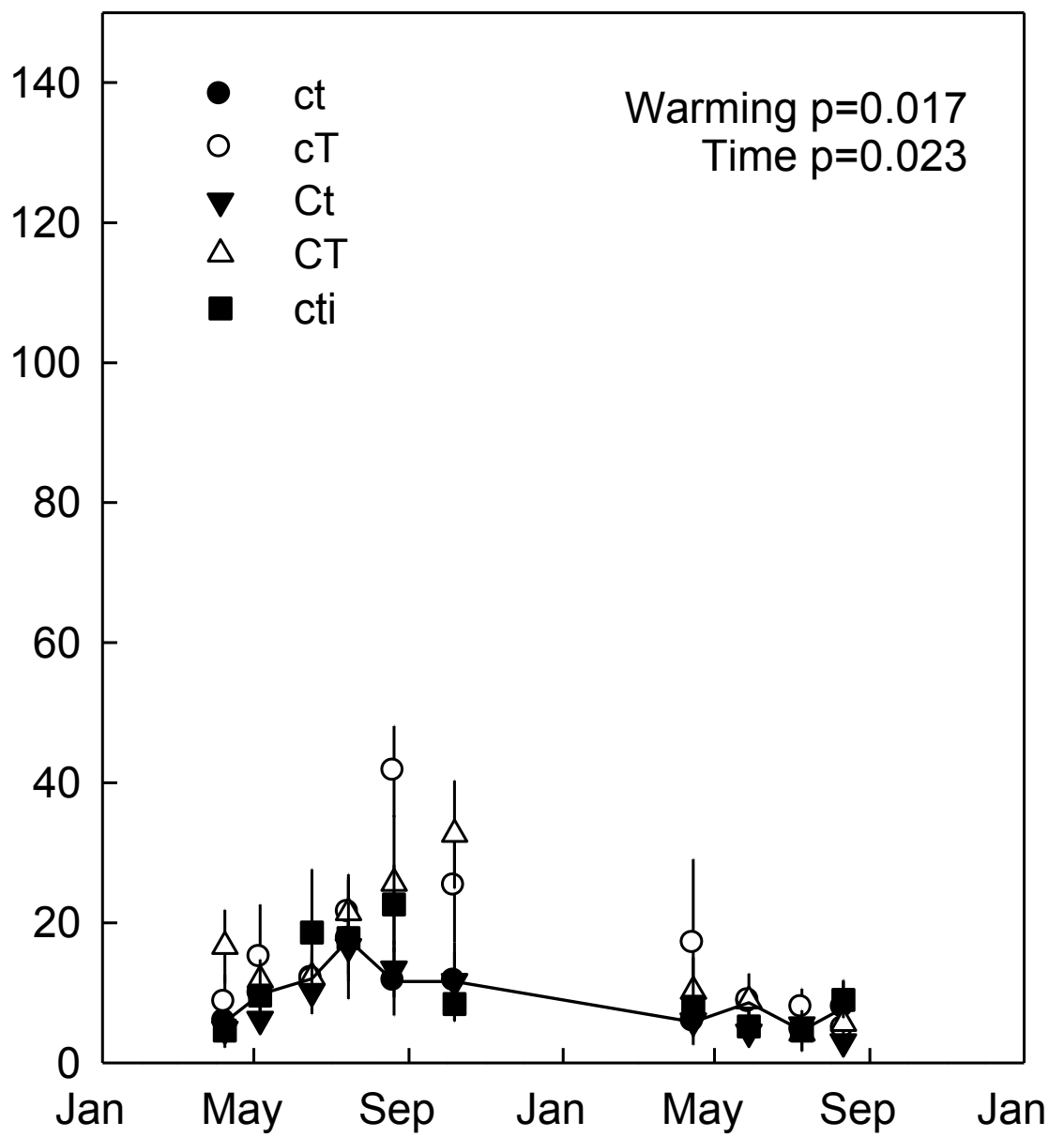

Figure S2. Number of roots produced (a) and number of roots lost from minirhizotron view (b) over 2009 and 2010 at PHACE. Values represent the number produced/lost since the previous observation summed over $15-40 \mathrm{~cm}$ depth. Plotted curve depicts dynamics under ambient conditions. ct: ambient $\mathrm{CO}_{2}$, unwarmed; cT: ambient $\mathrm{CO}_{2}$, warmed; $\mathrm{Ct}$ : elevated $\mathrm{CO}_{2}$, unwarmed; $\mathrm{CT}$ : elevated $\mathrm{CO}_{2}$, warmed; ct-i: ambient $\mathrm{CO}_{2}$, unwarmed, irrigated plots. Values are means of five replicates with standard errors. $\mathrm{p}$ values from repeated measures two-factor $\mathrm{ANOVA}\left(\mathrm{CO}_{2}\right.$, warming and interaction for main treatments) and one-factor for irrigation (ct vs ct-i; the effect of time was also significant in these analyses, p-values not shown). 

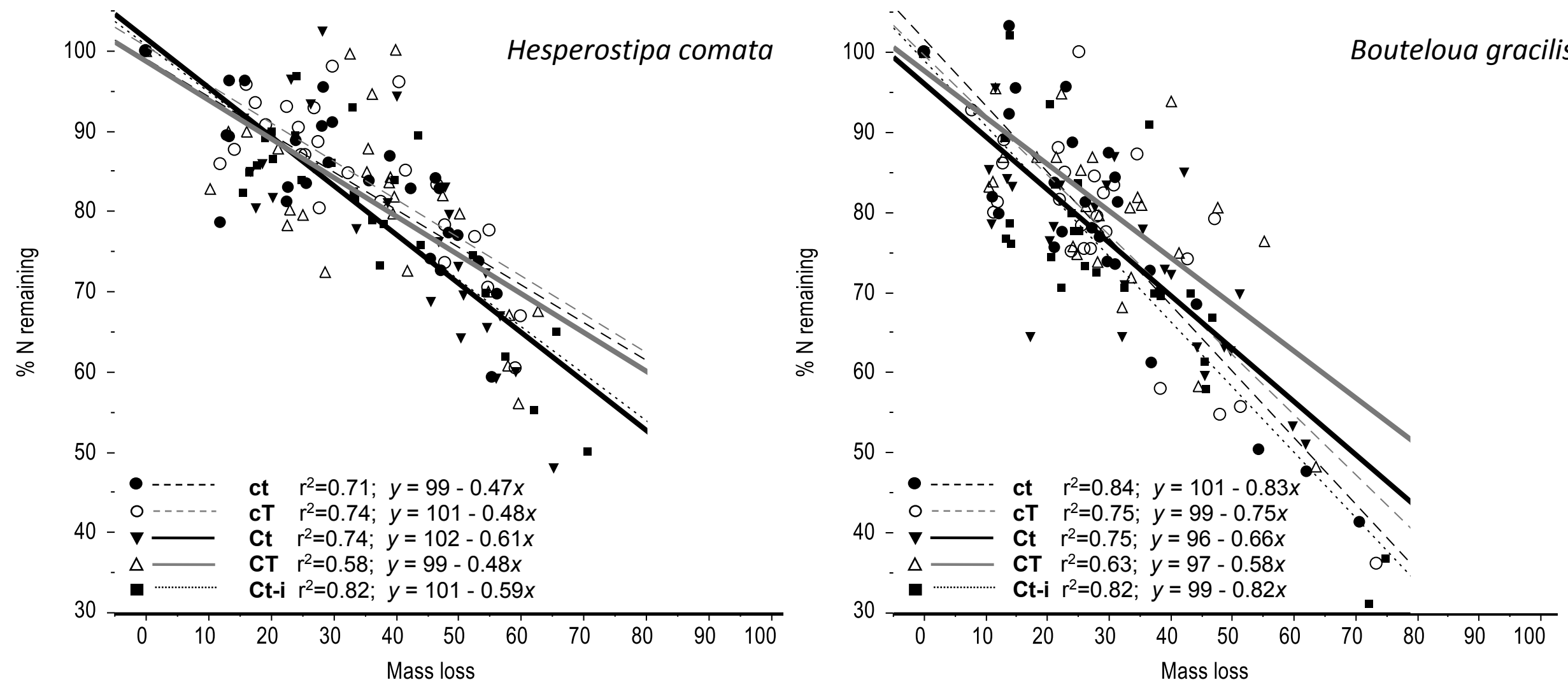

Figure S3. Percentage of initial N remaining in ash-free dry mass as a function of the percentage of mass loss over 3 years of decomposition of Hesperostipa comata and Bouteloua gracilis buried root litter at PHACE. ct: ambient $\mathrm{CO}_{2}$, unwarmed; cT: ambient $\mathrm{CO}_{2}$, warmed; $\mathrm{Ct}$ : elevated CO , unwarmed; $\mathrm{CT}$ : elevated $\mathrm{CO}_{2}$, warmed; ct-i: ambient $\mathrm{CO}_{2}$, unwarmed, irrigated plots. Values are individual data points for each experimental plot. 